\title{
PENGARUH PAJAK, TUNNELING INCENTIVE, DEBT COVENANT DAN \\ PROFITABILITAS TERHADAP KEPUTUSAN MELAKUKAN TRANSFER \\ PRICING
}

(Study Empiris pada Perusahaan Manufaktur yang Terdaftar di BEI Tahun 2013-2017)

\author{
Ahmad Junaidi \\ E-mail: rasi-jundi@yahoo.com.sg \\ Nensi Yuniarti. $Z^{2}$ \\ E-mail: yuniartinensi@gmail.com
}

\section{UNIVERSITAS MUHAMMADIYAH BENGKULU}

\begin{abstract}
This study aims to determine the effect of taxes, tunneling incentives, debt covenants, and profitability on the company's decision to transfer pricing. The data used in this study is secondary data obtained from accessing the web www.idx.co.id. The population of this research was manufacturing companies listed on the Indonesia Stock Exchange in 2013-2017. The sampling technique used was purposive sampling. The number of companies sampled in the study was 27 companies so that the total sample of the study was 135 observations. This study used the multiple linear regression analysis technique. The results of this study known there are still many variables outside the research that can explain transfer pricing.The determination coefficient is 0.441 which means that 44.1\%. It indicates that the company transfers pricing is influenced by these variables, while the rest is explained by other variables.Based on the result can be concluded that taxes, debt covenants and profitability has a positive effect on the decision to transfer pricing. While the tunneling incentive does not effect the decision to conduct transfer pricing.
\end{abstract}

Keywords: Tax, Tunneling Incentive, Debt Covenant, Profitability, and Transfer Pricing

\section{PENDAHULUAN}

Globalisasi membawa perubahan yang pesat pada setiap aspek kehidupan, termasuk perekonomian dunia yang ditandai dengan bertumbuhnya aktivitas bisnis berskala global yang membuat batas-batas negara hampir tidak ada. Hal ini memberi kebebasan bagi perusahaan dari penjuru dunia untuk memperluas atau mengembangkan aktivitas bisnisnya di berbagai negara yang dinilai memiliki potensi keuntungan yang lebih menjanjikan untuk aktivitas penjualan, pembelian bahan baku, pemberian jasa dan lain sebagainya yang terjadi antar divisi perusahaan dalam satu grup kepemilikan (Santoso (2004) dalam Rahadian (2015). 
Berdasarkan data yang diperoleh ada beberapa perusahaan manufaktur yang terbukti menyalahgunakan transfer pricing. Diantaranya PT. Toyota Motor Manufacturing Indonesia melakukan penghindaran pembayaran pajak senilai Rp 1,2 triliun dengan memanfaatkan skema jual beli, dengan menjual harga yang lebih rendah dibawah harga pasar kepada Toyota Asia Pasifik Singapura yang merupakan perusahaan terafiliasi, kemudian pihak Toyota Asia Pasifik Singapura menjual kembali dengan harga yang lebih tinggi. Adanya tarif pajak yang lebih rendah di negara Singapura yaitu sebesar $15 \%$ dibandingkan di Indonesia sebesar $25 \%$ hal ini dimanfaatkan oleh PT. Toyota Motor Manufacturing Indonesia untuk menghindari pajak (Sugiharto, 2015).

Beberapa penelitian telah mencoba meneliti tentang hubungan pajak pada transfer pricing, diantaranya oleh Pramana (2014), dan Noviastika dkk. (2016) yang menemukan bahwa pajak berpengaruh terhadap keputusan transfer pricing. Keputusan transfer pricing juga dipengaruhi oleh Tunneling incentive. Tunneling incentive adalah suatu prilaku dari pemegang saham mayoritas yang mentransfer aset dan laba perusahaan demi keuntungan mereka sendiri, tetapi pemegang biaya dibebankan pada pemegang saham minoritas (Hartati, 2014). Penelitian tentang tunneling incentive telah dilakukan oleh Noviastika dkk. (2016) dan Saraswati \& Sujana (2017) menemukan tunneling incentive mempunyai hubungan yang positif pada indikasi melakukan transfer pricing. Namun, penelitian yang dilakukan oleh Rosa, dkk. (2017), Syaifudin (2018) menunjukan hal yang berbeda, yaitu tunneling incentive tidak berpengaruh terhadap indikasi melakukan transfer pricing.

Motivasi yang dapat mempengaruhi keputusan perusahaan melakukan transfer pricing adalah debt covenant. Debt covenant merupakan perjanjian untuk melindungi pemberi pinjaman (lender atau creditor) dari tindakan-tindakan manajer terhadap kepentingan kreditur, seperti deviden yang berlebihan, pinjaman tambahan, atau membiarkan model kerja dan kekakayaan pemilik berada di bawah tingkat yang telah ditentukan, yang mana semuanya menurunkan keamanan (atau menaikan resiko) bagi kreditur yang telah ada. Penelitian tentang debt covenant telah dilakukan oleh Nuradilah dan Wibowo (2018) menyatakan bahwa debt covenant berpengaruh signifikan terhadap indikasi melakukan transfer pricing.

Profitabilitas merupakan kemampuan suatu perusahaan untuk mendapatkan laba (keuntungan) dalam suatu periode tertentu. Atau dapat dikatakan bahwa profitabilitas merupakan suatu indikator kontrak kinerja yang dilakukan manajemen dalam mengelolah kekayaan perusahaan yang ditunjukan oleh laba yang dihasilkan. Penelitian tentang profitabilitas telah dilakukan oleh Sari dan Mubarok (2018), Cahyadi dan Noviari (2018) menyatakan bahwa profitabilitas berpengaruh positif pada keputusan perusahaan dalam melakukan transfer pricing.

Berdasakan latar belakang tersebut maka penelitian ini akan menguji kembali pengaruh pajak, tunneling incentive, debt covenant, dan profitabilitas terhadap keputusan perusahaan melakukan transfer pricing. Penelitian ini menggunakan perusahaan manufaktur yang terdaftar di BEI tahun 2013-2017. Alasannya karena praktek transfer pricing ini terjadi hanya dalam perusahaan manufaktur, khususnya perusahaan- 
perusahaan multinasional yang memiliki anak perusahaan di luar negeri. Penggunaan sampel selama 5 tahun cukup untuk menggambarkan tentang kondisi perusahaan manufaktur di Indonesia yang melakukan praktek transfer pricing.

Berdasarkan hal tersebut, maka peneliti melakukan penelitian yang berjudul pengaruh pajak, Tunneling Incentive, Debt Covenant, Dan Profitabilitas Terhadap Keputusan Melakukan Transfer Pricing Pada Perusahaan Manufaktur Yang Terdaftar Di Bursa Efek Indonesia (Bei) Periode 2013 - 2017.

\section{TINJAUAN PUSTAKA}

\section{Teori Keagenan (Agency Theory)}

Jensen dan Meckling (1976), menjelaskan hubungan keagenan di dalam teori agensi (agency theory) bahwa perusahaan merupakan kumpulan kontrak (nexus of contract) antara pemilik sumber daya ekonomis (principal) dan manajer (agent) yang mengurus penggunaaan dan pengendalian sumber daya tersebut. Membatasi divergensi kepentingan dengan memberikan tingkat insentif yang layak kepada agen dan untuk mencegah moral hazard dari agen maka harus bersedia mengeluarkan biaya pengawasan (monitoring cost). Namun sebaliknya teori keagenan juga dapat mengimplikasikan adanya asimetri informasi. Konflik yang timbul antar pemilik disebut konflik antar kelompok atau agency conflict. Konflik ini terjadi karena adanya kecenderungan manajer kurang mementingkan tujuan perusahaan serta lebih mementingkan kepentingan pribadi. Tujuan adanya pemisahan pengelolaan dari kepemilikan perusahaan yaitu, agar pemilik perusahaan (pemegang saham) memperoleh keuntungan yang semaksimal mungkin dengan biaya yang seefisien mungkin dengan dikelolahnya perusahaan oleh tenaga-tenaga profesional (Sutedi, 2012:10 dalam Noviastika dkk, 2016).

\section{Teori Sinyal (Signalling Theory)}

Signaling theory mengasumsikan bahwa terdapat asimetri informasi antara manajer dengan investor atau calon investor. Manajer dipandang memiliki informasi tentang perusahaan yang tidak dimiliki oleh investor maupun calon investor. Teori persinyalan menjelaskan alasan pentingnya perusahaan menyajikan informasi kepada publik (Morris, 1987 dalam Pradana, 2018). Informasi tersebut bisa berupa laporan keuangan, informasi kebijakan perusahaan maupun informasi lain yang diungkapkan secara sukarela oleh manajemen perusahaan. Hubungan teori sinyal dengan transfer pricing adalah perusahaan multinasional akan mencoba untuk mengalokasikan pendapatan mereka dari negara dengan tarif pajak tinggi ke negara dengan tarif pajak lebih rendah untuk meminimalisir total beban biaya dan memaksimalkan profit perusahaan. Hal ini menjadi salah satu sinyal tentang isu dari perusahaan yang akan menjadi kabar baik bahwa perusahaan memiliki laba yang tinggi pada laporan laba rugi tahunan perusahaan sehingga memberikan kesan bahwa perusahaan akan bertahan lama di masa depan (Muhammadi, dkk. 2016).

\section{Transfer Pricing}

Transfer pricing merupakan harga yang terkandung pada setiap produk atau jasa dari satu devisi ke devisi lain dalam perusahaan yang sama atau antar perusahaan yang 
mempunyai hubungan istimewa (Yuniasih, dkk., 2012:7). Transfer pricing dproksikan dengan nilai Related Party Transaction (RPT) (Kiswanto \& Purwaningsih, 2014).

$$
R P T=\frac{\text { Piutang Transaksi Pihak Berelasi }}{\text { Total Piutang }}
$$

\section{Pajak}

Menurut Rochmat Soemitro pajak adalah iuran rakyat kepada kas negara berdasarkan undang-undang (yang dapat dipaksakan) dengan tidak mendapat jasa timbal balik (kontraprestasi) yang langsung dapat ditunjukan dan digunakan untuk membayar pengeluaran umum. Pajak dalam penelitian ini di proksikan dengan Effective tax rate (ETR) yang merupakan perbandingan tax expense dikurangi deffered tax expense dibagi dengan laba kena pajak (Yuniasih, dkk. 2012).

$$
\text { ETR }=\frac{\text { tax expense }- \text { deffered tax expense }}{\text { laba kena pajak }}
$$

\section{Tunneling Incentive}

Tunneling merupakan perilaku manajemen atau pemegang saham mayoritas yang mentransfer aset dan profit perusahaan untuk kepentingan mereka sendiri, namun biaya dibebankan kepada pemegang saham minoritas (Mutamimah, 2009:166). Tunneling incentive diproksikan dengan persentase kepemilikan saham diatas 20\% sebagai pemegang saham pengendali oleh perusahaan pihak asing (Yuniasih, dkk. 2012).

$$
\text { KSA }=\frac{\text { Jumlah Kepemilikan Asing }}{\text { Total Saham yang Beredar }}
$$

\section{Debt Covenant}

Debt covenant adalah kontrak yang ditujukan pada peminjam oleh kreditor untuk membatasi aktivitas yang mungkin merusak nilai pinjaman dan recovery pinjaman (Cochran, 2001 dalam Indrasti, 2016: 353). Debt covenant diproksikan dengan rasio hutang menggunakan Debt to Equity Ratio (DER) (Pramana, 2014).

$$
\text { DER }=\frac{\text { Total Hutang }}{\text { Total Modal }}
$$

\section{Profitabilitas}

Profitabilitas adalah kemampuan perusahaan untuk memperoleh keuntungan. Menurut Sudarmadji dan Sularto (2007) dalam Rahadian (2015: 4).Profitabilitas dalam penelitian ini diproyeksikan dengan Return On Asset (ROA). (Cahyadi dan Noviari, 2018).

$$
\text { ROA }=\frac{\text { Laba Setelah Pajak }}{\text { Total Asset }}
$$

\section{Pengaruh Pajak terhadap Keputusan Transfer Pricing}

Transaksi transfer pricing sering kali digunakan perusahaan untuk meminilmalkan pajak yang seharusnya dibayar. Dalam transfer pricing, perusahaan multinasional cenderung menggeser kewajiban perpajakannya dari negara-negara yang memiliki tarif pajak yang tinggi (high tax countries) ke negara-negara yang menerapkan tarif pajak rendah (low tax countries) dengan cara memperkecil harga jual antara perusahaan dalam satu grup. Jacob (1996) dalam Yuniasih, dkk (2012) menemukan bahwa transfer antar perusahaan besar dapat mengakibatkan pembayaran pajak lebih rendah secara global pada umumnya. Penelitian tersebut menemukan bahwa perusahaan multinasional 
memperoleh keuntungan karena pergeseran pendapatan dari negara-negara dengan pajak tinggi ke negara dengan pajak rendah. Hal tersebut di dukung oleh pendapat Gusnardi (2009: 39) yang mengemukakan bahwa untuk meminimalisir total beban pajak keseluruhan, maka praktik transfer pricing dipilih oleh perusahaan-perusahaan multinasional.

H1:Pajak Berpengaruh Positif terhadap keputusan perusahaan untuk melakukan Transfer Pricing

\section{Pengaruh Tunneling Incentive terhadap Keputusan Melakukan Transfer Pricing}

Tunneling merupakan tindakan pengalihan aktiva dan laba perusahaan untuk kepentingan pemegang saham pengendali yang mengendalikan saham minoritas (Ahory et al. 2010 dalam Saraswati dan Sujana, 2017). Transaksi antar pihak berelasi digunakan untuk mengalihkan aset lancar lainnya keluar dari perusahaan melalui penentuan harga yang tidak wajar untuk kepentingan pemegang saham pengendali. Pembelian barang atau jasa diatas nilai wajar dan penjualan barang atau jasa dibawah harga wajar merupakan salah satu cara melakukan tunneling. Dalam penelitian Sujana (2017) menemukan bahwa tunneling incentive berpengaruh positif signifikan terhadap transfer pricing. Berdasarkan rumusan diatas maka hipotesis kedua dalam penelitian ini adalah sebagai berikut.

$\mathrm{H}$ 2:Tunneling incentive berpengaruh positif terhadap keputusan perusahaan untuk melakukan transfer pricing

\section{Pengaruh Debt Covenant terhadap Keputusan Transfer Pricing}

Semakin tinggi rasio hutang atau ekuitas perusahaan semakin besar pula kemungkinan bagi manajer untuk memilih metode akuntansi yang dapat menaikkan laba. Salah satu cara yang digunakan perusahaan untuk dapat menaikkan laba dan menghindari peraturan kredit adalah dengan transfer pricing (Pramana, 2014). Penelitian yang telah dilakukan oleh Wibowo (2018), menunjukan hasil bahwa debt covenant berpengaruh signifikan positif terhadap keputusan perusahaan melakukan transfer pricing. Berdasarkan rumusan diatas maka hipotesis ketiga dalam penelitian ini adalah sebagai berikut.

H3: Debt covenant berpengaruh positif terhadap keputusan peursahaan untuk melakukan transfer pricing

\section{Pengaruh Profitabilitas terhadap Keputusan Transfer Pricing}

Profitabilitas perusahaan menggambarkan efektivitas manajemen perusahaan dalam mengelolah perusahaan sehingga dapat mencapai target yang diharapkan oleh pemilik perusahaan. Meningkatkan profitabilitas suatu perusahaan menyebabkan kewajiban pada sektor perpajakan juga akan meningkat (Cahyadi \& Noviari, 2018). Penelitian Mubarok (2016), Cahyadi dan Noviari (2018) menunjukan bahwa profitabilitas berpengaruh positif terhadap agresivitas transfer pricing. Berdasarkan uraian diatas, maka hipotesis keempat penelitian ini adalah sebagai berikut:

H4: Profitabilitas berpengaruh positif terhadap keputusan perusahaan untuk melakukan transfer pricing. 


\section{METODE PENELITIAN}

\section{Tempat dan Waktu Penelitian}

Penelitian ini dilakukan pada perusahaan manufaktur yang terdaftar di BEI tahun 20132017. Pengambilan sampel dengan menggunakan metode purposive sampling, yaitu teknik pengambilan sampel dengan mempertimbangkan kriteria berikut ini:

Tabel 1: Proses Pemilihan Sampel

\begin{tabular}{|l|c|}
\hline \multicolumn{1}{|c|}{ Kriteria } & Jumlah \\
\hline Seluruh Perusahaan manufaktur yang terdaftar di BEI tahun 2013-2017 & 132 \\
\hline $\begin{array}{l}\text { Perusahaan manufaktur yang tidak mempublikasikan laporan tahunan di } \\
\text { Bursa Efek Indonesia berturut-turut selama tahun 2013-2017 }\end{array}$ & $(14)$ \\
\hline $\begin{array}{l}\text { Perusahaan manufaktur yang mengalami kerugian selama periode penelitian } \\
\text { Perusahaan manufaktur yang tidak dikendalikan oleh perusahaan asing } \\
\text { dengan persentase kepemilikan saham 20\% atau lebih sebagai pemegang } \\
\text { saham pengendali }\end{array}$ & $(22)$ \\
\hline $\begin{array}{l}\text { Perusahaan manufaktur yang menyajikan laporan keuangan dalam mata } \\
\text { uang asing }\end{array}$ & $(26)$ \\
\hline $\begin{array}{l}\text { Perusahaan manufaktur yang tidak menyajikan data lengkap sesuai dengan } \\
\text { variabel penelitian yang dibutuhkan }\end{array}$ & $(13)$ \\
\hline \begin{tabular}{l} 
Jumlah Sampel Akhir \\
\hline Tahun Pengamatan
\end{tabular} & 27 \\
\hline \begin{tabular}{l} 
Jumlah Pengamatan (27 perusahaan x 5 tahun) \\
\hline
\end{tabular} & 5 \\
\hline
\end{tabular}

Sumber: Data Sekunder Diolah, 2019

\section{Teknik Analisis Data}

Teknik analisis data dalam penelitian ini menggunakan uji:

1. Uji statistik Deskriptif

Pengujian ini digunakan untuk memberikan gambaran umum atau karakteristik data yang digunakan dalam penelitian ini, yaitu suatu data dapat dilihat dari nilai rata-rata (mean), standar deviasi, nilai maksimum dan minimum.

2. Uji Asumsi Klasik

Pengujian ini dilakukan untuk menguji kelayakan model regresi yang digunakan agar pengujian yang dihasilkan tidak bias, maka harus terlebih dahulu memenuhi uji asumsi klasik (Ghozali:2013). Pengujian asumsi terdiri dari uji normalitas, uji multikolonearitas, uji autokorelasi dan uji heterokesdasitas.

3. Uji Hipotesis

Teknik analisis data yang digunakan dalam penelitian ini adalah regresi linear berganda. Analisis ini digunakan untuk menguji apakah terdapat pengaruh dua atau lebih variabel independen terhadap satu variabel dependen (Ghozali, 2013). Model dalam penelitian ini adalah sebagai berikut: 


$$
\mathbf{Y}=\mathbf{a}+\mathbf{b} 1 \mathbf{X} 1+\mathbf{b} 2 \mathbf{X} 2+\mathbf{b} 3 \mathbf{X} 3+\mathbf{b} 4 \mathbf{X} 4+\varepsilon
$$

\author{
Y: Transfer Pricing \\ X1: Pajak \\ $\mathrm{X} 2$ : Tunneling Incentive \\ X3: Debt Covenant \\ X4: Profitabilitas \\ a: konstanta \\ b: koefisien Regresi \\ e: Error Term
}

\title{
Analisis Sensitivitas
}

Menurut Hasibuan (2011) analisis sensitivitas merupakan uji untuk melihat seberapa sensitif model regresi ketika salah satu variabel diganti. Variabel yang diganti adalah variabel yang secara parsial berpengaruh signifikan dan mendekati signifikan terhadap variabel respon dengan menggunakan transformasi eksponensial.

\section{HASIL PENELITIAN DAN PEMBAHASAN \\ Statistik Deskriptif}

Statistik deskriptif ini memberikan gambaran mengenai nilai minimum, nilai maksimum, nilai rata-rata, dan standar deviasi (Ghozali, 2013).

Tabel 2

Deskriptif Statistik Variabel Penelitian

\begin{tabular}{|l|r|r|r|r|r|}
\hline & $\mathrm{N}$ & \multicolumn{1}{c|}{ Minimum } & \multicolumn{1}{c|}{ Maximum } & \multicolumn{1}{c|}{ Mean } & \multicolumn{1}{c|}{ Std. Deviation } \\
\hline Transfer Pricing & 135 & .001743 & .982604 & .27467434 & .307061838 \\
Pajak & 135 & .017553 & 1.118974 & .36664937 & .194657067 \\
Tunneling Incentive & 135 & .213987 & .989482 & .58612381 & .209888868 \\
& 135 & .091457 & 2.654552 & .71118367 & .445665641 \\
Debt Covenant & 135 & .000010 & .401000 & .15892458 & .102538084 \\
Profitabilitas & 135 & & & & \\
\hline
\end{tabular}

Sumber:Data Sekunder Diolah, 2019

Berdasarkan data diatas, rata-rata variabel transfer pricing adalah 27,46\% dari 135 sampel atau sebanyak 37 perusahaan sampel memiliki hubungan istimewa. Variabel pajak mempunyai nilai rata-rata 0.36664937 , standar deviasi 0.194657067 dengan nilai minimum dan maksimum masing-masing sebesar 0.017553 dan 1.118974. Variabel tunneling incentive mempunyai nilai rata-rata 0.58612381 , standar deviasinya 0.209888868, dengan nilai minimum dan maksimum masing-masing sebesar 0.213987 dan 0.989482. Variabel debt covenant mempunyai nilai rata-rata sebesar 0.71118367 , standar deviasinya 0.445665641 , dengan nilai minimum dan maksimum masing-masing 
sebesar 0.091457 dan 2.654552. Variabel profitabilitas mempunyai nilai rata-rata sebesar 0.15892458 , standar deviasinya 0.102538084 .

\section{Hasil Pengujian Asumsi Klasik Uji Normalitas}

Tabel. 3

Hasil Pengujian Normalitas

\begin{tabular}{|l|r|}
\hline & \multicolumn{2}{|l|}{$\begin{array}{l}\text { Unstandardized } \\
\text { Residual }\end{array}$} \\
\hline $\mathrm{N}$ & 95 \\
\hline Kolmogorov-Smirnov Z & .916 \\
\hline Asymp. Sig (2-tailed) & .372 \\
\hline
\end{tabular}

Sumber: Data Sekunder Diolah, 2019

Berdasarkan hasil perbaikan data observasi menjadi 95 observasi tabel 3 menunjukan semua variabel telah terdistribusi secara normal dengan nilai probabilitas $>0,05$ yang artinya data telah terdistribusi secara normal.

\section{Uji Autokorelasi}

Tabel. 4

Hasil Uji Autokorelasi

\begin{tabular}{|c|c|c|c|c|c|}
\hline \multicolumn{6}{|c|}{ Model Summary $^{\text {b }}$} \\
\hline Model & $\mathrm{R}$ & R Square & $\begin{array}{l}\text { Adjusted R } \\
\text { Square }\end{array}$ & $\begin{array}{l}\text { Std. Error of the } \\
\text { Estimate }\end{array}$ & Durbin-Watson \\
\hline 1 & $.681^{\mathrm{a}}$ & .464 & .441 & .169216625 & 1.776 \\
\hline
\end{tabular}

Pada tabel 4 dapat dilihat bahwa model persamaan telah bebas dari masalah autokorelasi karena pada model persamaan nilai dW lebih besar dari pada dU dan lebih rendah daripada 4-dU yaitu dU $<\mathrm{dW}<4-\mathrm{dU}$ sehingga dapat disimpulkan bahwa data bebas autokorelasi.

\section{Uji Multikolinearitas}

Tabel. 5

Hasil Uji Multikolinearitas

\begin{tabular}{|l|c|c|}
\hline \multirow{2}{*}{\multicolumn{1}{c|}{ Variabel }} & \multicolumn{2}{c|}{ Collinearity Statistics } \\
\cline { 2 - 3 } & Tolerance & VIF \\
\hline Pajak & 0,709 & 1,410 \\
\hline Tunneling Incentive & 0,873 & 1,145 \\
\hline Debt Covenant & 0,852 & 1,174 \\
\hline Profitabilitas & 0,834 & 1,199 \\
\hline
\end{tabular}

Sumber: Data Sekunder diolah, 2019 
Berdasarkan tabel 5 maka dapat dilihat bahwa model regresi terbebas dari masalah multikolinearitas karena nilai tolerance masing-masing variabel lebih dari $>0,1$ dan nilai VIF kurang dari < 10.

\section{Uji Heteroskedastisitas}

Tabel. 6

Hasil Uji Heteroskedatisitas

\begin{tabular}{|l|r|r|}
\hline \multicolumn{1}{|c|}{ MODEL } & \multicolumn{1}{c|}{ t } & \multicolumn{1}{c|}{ Sig } \\
\hline 1 (Constant) & 2.746 & .007 \\
Pajak & -1.338 & .184 \\
Tunneling Incentive & .838 & .404 \\
Debt Covenant & .795 & .429 \\
Profitabilitas & .102 & .919 \\
\multicolumn{1}{|c|}{ Sumber: Data Sekunder diolah, 2019}
\end{tabular}

Berdasarkan tabel 6 dapat dilihat bahwa tidak terdapat model persamaan yang terkena masalah heteroskedastisitas karena signifikansi masing-masing variabel $>0,05$.

\section{Analisis Regresi Linear Berganda}

Tabel. 7

Hasil Uji Regresi Linear Berganda

\begin{tabular}{|c|c|c|c|c|c|}
\hline \multirow[b]{2}{*}{ Model } & \multicolumn{2}{|c|}{$\begin{array}{l}\text { Unstandardized } \\
\text { Coefficients }\end{array}$} & \multirow{2}{*}{$\begin{array}{c}\text { Standardized } \\
\text { Coefficients } \\
\text { Beta }\end{array}$} & \multirow[b]{2}{*}{$\mathrm{t}$} & \multirow[b]{2}{*}{ Sig. } \\
\hline & $\mathrm{B}$ & Std. Error & & & \\
\hline 1 (Constant) & .003 & .066 & & .044 & .965 \\
\hline Pajak & .428 & .130 & .301 & 3.283 & .001 \\
\hline Tunneling Incentive & .020 & $.091 \mid$ & .018 & .220 & .826 \\
\hline Debt Covenant & .266 & .058 & .386 & 4.616 & .000 \\
\hline Profitabilitas & .502 & .197 & .215 & 2.550 & .012 \\
\hline $\mathrm{F}$ & & 19.511 & & & \\
\hline $\mathrm{R} 2$ & & .464 & & & \\
\hline Adjusted R2 & & .441 & & & \\
\hline *Signifikansi pada 0,05 & & & & & \\
\hline
\end{tabular}

Berdasarkan tabel diatas maka dapat diperoleh model persamaan regresi sebagai berikut:

$$
\mathrm{Y}=0,003+(0,428) \mathrm{X} 1+(0,020) \mathrm{X} 2+(0,266) \mathrm{X3}+(0,502) \mathrm{X} 4+\varepsilon
$$

Nilai konstanta sebesar 0,003 artinya bahwa apabila semua variabel independen, yaitu pajak (ETR), tunneling incentive (KSA), debt covenant (DER), dan profitabilitas (ROA) dianggap konstan (bernilai 0), maka transfer pricing (RPT) akan meningkat sebesar 0,003 . Koefisien untuk pajak (ETR) sebesar 0,428, artinya apabila variabel pajak mengalami kenaikan 1 sedangkan variabel lainnya dianggap konstan (bernilai 0), maka transfer pricing mengalami kenaikan sebesar 0,428. Koefisien untuk tunneling incentive (KSA) sebesar 0, 020 artinya apabila variabel tunneling incentive mengalami kenaikan 1 sedangkan variabel lainnya dianggap konstan (bernilai 0), maka transaksi transfer 
pricing mengalami kenaikan sebesar 0,020. Koefisien debt covenant sebesar 0,266, artinya apabila variabel debt covenant mengalami kenaikan 1 sedangkan variabel lainnya dianggap konstan (bernilai 0), maka transaksi transfer pricing mengalami kenaikan sebesar 0,266.

Koefisien profitabilitas (ROA) sebesar 0,502 artinya apabila variabel profitabilitas mengalami kenaikan 1 sedangkan variabel lainnya dianggap konstan (bernilai 0), maka transaksi transfer pricing mengalami kenaikan sebesar 0,502. Berdasarkan tabel diatas nilai $\mathrm{F}$ model penelitian diperoleh sebesar 19.511 dengan nilai signifikansi 0,000 yang lebih kecil dari 0,05. Hal ini menunjukan bahwa pajak, tunneling incentive, debt covenant dan profitabilitas berpengaruh secara simultan terhadap transfer pricing dan model dalam penelitian ini fit.

Berdasarkan tabel diatas nilai koefisien determinasi (Adjusted $R$ Square) adalah sebesar 0.441 , yang berarti variabel dependen yang dapat dijelaskan oleh variabel independen sebesar 0,441 atau 44,1\%. Hal ini ini menunjukan bahwa 44,1\% tindakan transaksi transfer pricing dipengaruhi oleh pajak, tunneling incentive, debt covenant, danprofitabilitas. Sedangkan sisanya 55,9\% dipengaruhi oleh variabel lain yang tidak diteliti dalam penelitian ini.

Hasil perhitungan regresi diperoleh bahwa variabel pajak, tunneling incentive, debt covenant, dan profitabilitas memiliki arah koefisien positif yang sesuai dengan yang dihipotesiskan.

\section{Variabel pajak berpengaruh terhadap transfer pricing}

Pengujian hipotesis 1 mengenai pengaruh variabel pajak terhadap transfer pricing menunjukan nilai t sebesar 3.283 dengan signifikansi sebesar 0,001. Hal ini berarti bahwa pajak berpengaruh positif signifikan terhadap transfer pricing. Hal tersebut mengindikasikan bahwa semakin besar jumlah beban pajak yang harus dibayarkan perusahaan kepada negara maka perusahaan manufaktur yang berorientasi pada laba semakin terpicu untuk melakukan berbagai cara dalam rangka meminimalisir jumlah pajak yang harus dibayar dengan salah satunya cara menerapkan transfer pricing. Praktik transfer pricing tersebut dilakukan dengan memperkecil harga jual. Hal tersebut dilakukan untuk merekayasa laba perusahaan sehingga laba yang diperoleh pada tahun tertentu akan terlihat lebih rendah bahkan rugi dan secara tidak langsung akan berdampak pada nilai pajak yang dibayarkan (Nisa, 2018).

2. Variabel tunneling incentive terhadap transfer pricing

Pengujian hipotesis 2 mengenai pengaruh tunneling incentive terhadap transfer pricing menunjukan nilai t sebesar 220 dengan signifikansi sebesar 0,826 . Hasil ini berarti bahwa tunneling incentive tidak berpengaruh terhadap transfer pricing. Hal tersebut mengindikasikan bahwa pemegang saham asing tidak menggunakan hak kendalinya untuk memerintahkan manajemen dalam melakukan transfer pricing atau bisa juga diartikan bahwa ada atau tidaknya pemegang saham asing, perusahaan akan tetap melakukan transfer pricing (Nurjanah, dkk. 2015).

\section{Variabel debt covenant terhadap transfer pricing}

Pengujian hipotesis 3 mengenai pengaruh debt covenant terhadap transfer pricing menunjukan nilai t sebesar 4.616 dengan nilai signifikansi sebesar 0,000 . Hal ini berarti bahwa debt covenant berpengaruh positif signifikan terhadap transfer pricing. 
Untuk perusahaan yang mengejar profit atau laba yang tinggi salah satu caranya adalah menghindari peraturan kredit dengan cara melakukan transaksi transfer pricing (Pramana, 2014).Perjanjian hutang merupakan syarat yang harus dipenuhi perusahaan untuk mempertahankan rasio-rasio umumnya yang dikaitkan dengan data akuntansi perusahaan, misalnya rasio hutang terhadap total modal. Semakin tinggi hutang perusahaan maka syarat-syarat yang diajukan oleh kreditur akan semakin ketat.

\section{Variabel profitabilitas berpengaruh terhadap transfer pricing}

Hasil pengujian hipotesis 4 mengenai pengaruh profitabilitas terhadap transfer pricing menunjukan nilai $\mathrm{t}$ sebesar 2.550 dengan signifikansi 0,012 , yang berarti profitabilitas berpengaruh positif signifikan terhadap transfer pricing. Semakin profitable perusahaan, maka akan memberikan sinyal positif bagi para investor untuk mendapatkan keuntungan. Terdapat kecenderungan manajemen memanfaatkan transaksi transfer pricing untuk memaksimalkan bonus yang akan mereka terima jika bonus tersebut didasarkan pada laba perusahaan. Jadi dapat disimpulkan bahwa manajer akan cenderung melakukan tindakan yang mengatur laba bersih dengan menggunakan praktik transfer pricing untuk memaksimalkan bonus yang akan mereka terima (Nurjanah dkk., 2016).

\section{Analisis Sensitivitas}

Analisis sensifitas dilakukan untuk menguji seberapa sensitive model bila salah satu variabel diganti (Hasibuan, 2011). Analisis sensifitas yang digunakan pertama adalah dengan menggunakan variabel debt covenant (DER).

Tabel. 8

Uji F Debt Covenant (DER)

\begin{tabular}{|l|c|c|}
\hline Model & F & Sig. \\
\hline Regression & $\mathbf{1 7 . 8 6 5}$ & $\mathbf{. 0 0 0}$ \\
\hline
\end{tabular}

Tabel. 9

Hasil Uji t Debt Covenant (DER)

\begin{tabular}{|l|r|r|}
\hline \multicolumn{1}{|c|}{ Variabel } & t & sig \\
\hline X1 (Pajak) & 3.417 & .001 \\
\hline X2 (Tunneling Incentive) & .116 & .908 \\
\hline X4 (Profitabilitas) & 2.492 & .015 \\
\hline EXP_X3 (Debt Covenant & 4.116 & .000 \\
\hline
\end{tabular}

Setelah dilakukan uji sensitivitas dengan menggunakan debt covenant yang menggunakan perbandingan total hutang dengan total modal, dengan munggunakan transformasi eksponensial, maka tetap diperoleh bahwa uji $\mathrm{F}$ dan uji t (untuk variabel debt covenant) signifikan. Perbandingan: pada model sebelumnya diperoleh statistik $\mathrm{F}$ $=19.511$ dengan $\mathrm{p}$-value $=0,000$, sedangkan variabel X3 ditransformasi menggunakan transformasi eksponensial (exp) diperoleh nilai statistik $\mathrm{F}=17.865$ dan $\mathrm{p}$-value $=0,000$ hal tersebut sejalan dengan uji $\mathrm{t}$, dimana sebelum transformasi p-value untuk X3 sebesar 0,000 sedangkan setelah transformasi diperoleh nilai $\mathrm{p}$-value $=0,000$. Hasil ini sama dengan sebelum dilakukan transformasi eksponesial pada variabel X3, jadi dapat disimpulkan bahwa model tidak sensitif terhadap transformasi eksponensial pada variabel X3. Kemudian sebagai pembanding dilakukan transformasi eksponensial pada 
variabel X4, untuk melihat apakah transformasi ini menyebabkan perubahan yang signifikan pada model, hasilnya sebagai berikut:

Tabel 10

Uji F Profitabilitas (ROA)

\begin{tabular}{|l|c|c|}
\hline \multicolumn{1}{|c|}{ Model } & F & Sig. \\
\hline Regression & $\mathbf{1 9 . 4 5 3}$ & $\mathbf{. 0 0 0}$ \\
\hline
\end{tabular}

Tabel 11

Hasil Uji t Profitabilitas (ROA)

\begin{tabular}{|l|r|r|}
\hline \multicolumn{1}{|c|}{ Variabel } & t & sig \\
\hline X1 (Pajak) & 3.336 & .001 \\
\hline X2 (Tunneling Incentive) & .188 & .852 \\
\hline X3 (Debt Covenant) & 2.523 & .000 \\
\hline EXP_X4 (Profitabilitas) & 4.625 & .013 \\
\hline
\end{tabular}

Setelah dilakukan uji sensifitas dengan menggunakan variabel X4 dengan munggunakan transformasi eksponensial, maka tetap diperoleh bahwa uji $\mathrm{F}$ dan uji $\mathrm{t}$ (untuk variabel X4) signifikan.

Perbandingan:pada model sebelumnya diperoleh statistik $\mathrm{F}=19.511$ dengan $\mathrm{p}$-value $=$ 0,000 , sedangkan setelah variabel $\mathrm{X} 4$ ditransformasi menggunakan transformasi eksponensial diperoleh nilai statistik $\mathrm{F}=19.453$ dan $\mathrm{p}$-value $=0,000$, hal tersebut sejalan dengan uji t, dimana sebelum transformasi p-value untuk X4 sebesar 0,012 sedangkan setelah transformasi diperoleh nilai $\mathrm{p}$-value $=0,013$, hal ini menunjukan bahwa kedua model signifikan, namun model sebelum di transformasi lebih baik.

\section{KESIMPULAN}

Berdasarkan hasil yang diperoleh dari pengelolahan dan analisis data maka dapat diambil kesimpulan sebagai berikut:

1. Pajak berpengaruh positif terhadap keputusan perusahaan melakukan transfer pricing. Hal ini menunjukan semakin rendah effective tax rate maka dianggap semakin baik nilai effective tax rate di suatu perusahaan.

2. Tunneling incentive tidak berpengaruh positif terhadap keputusan perusahaan melakukan transfer pricing. Hal tersebut mengindentifikasikan bahwa pemegang saham asing tidak menggunakan hak kendalinya untuk memerintahkan manajemen dalam melakukan transfer pricing.

3. Debt covenant berpengaruh positif terhadap keputusan perusahaan melakukan transfer pricing. Artinya Semakin tinggi rasio hutang perusahaan, maka manajer perusahaan akan memilih metode akuntansi yang dapat menaikan laba perusahaan.

4. Profitabilitas berpengaruh positif terhadap keputusan perusahaan melakukan transfer pricing. Artinya Semakin besar profitabilitas akan meningkatkan agresivitas transfer pricing atau semakin kecil profitabilitas akan menurunkan agresivitas transfer pricing. 


\section{SARAN}

Berdasarkan keterbatasan yang terdapat pada penelitian ini, maka peneliti mengajukan beberapa saran dalam upaya perbaikan penulisan untuk penelitian selanjutnya antara lain:

1. Sampel yang digunakan pada penelitian ini hanya terfokus pada perusahaan manufaktur yang terdaftar di Bursa Efek Indonesia (BEI), sehingga tidak dapat digeneralisasikan pada jenis industri lain. Untuk penelitian selanjutnya disarankan memperbesar sampel penelitian tidak hanya terbatas pada perusahaan manufaktur saja, tapi juga pada perusahaan sektor lain seperti pertambangan, perkebunan, keuangan dan non keuangan.

2. Peneliti yang akan datang hendaknya menambahkan variabel lain seperti exchange rate, ittangible asset, corporate governance, bonus plan, dan lainnya. Serta, untuk penelitian selanjutnya diharapkan dapat memperpanjang periode waktu penelitian (time series).

\section{DAFTAR PUSTAKA}

Cahyadi, A. S., \& Noviari, N. (2018). Pengaruh Pajak, Exchange Rate, Profitabilitas, dan Leverage pada Keputusan Melakukan Transfer Pricing. E-Jurnal Akuntansi Universitas Udayana, 24(2), 1441-1473

Ghozali, I. (2013). Aplikasi Analisis Multivariate Dengan Program IBM SPSS 21. Semarang: Badan Penerbit Universitas Diponegoro.

Hartati, W., Desmiyawati, \& Azlina, N. (2014) Analisis Pengaruh Pajak dan Mekanisme Bonus terhadap Keputusan Transfer Pricing.Simposium Nasional Akuntansi XVII Mataram. 24-27 September: 1-18

Indrasti, A. W. (2016). Pengaruh Pajak, Kepemilikan Asing, Bonus Plan, dan Debt Convenant, terhadap Keputusan Untuk Melakukan Transfer Pricing pada Perusahaan Manufaktur yang Terdaftar di BEI tahun 2012-2015. Jurnal Vol. 9 No. 3 Desember 2016

Jensen, M., \& W.H. Meckling. (1976). Theory Of The Firm: Managerial Behavior, Agency Cost And Ownership Structure. Journal Of Financial Economics 3. Hal. 305-360.

Muhammadi, A. H., Ahmed, Z., \& Habib, A. (2016). Multinational transfer pricing of intangible assets: Indonesian tax auditors' perspectives. AsianReview of Accounting, 24(3), 313-337.

Noviastika, Dwi., Mayowan, Yuniadi,. \& Suhartini Karjo. (2016). Pengaruh Pajak, Tunneling Incentive, dan Good Corporate Governance (GCG) terhadap Indikasi Melakukan Transfer Pricing pada Perusahaan Manufaktur yang Terdaftar di Bursa Efek Indonesia. Jurnal Perpajakan, 8(1): 1-9 
Pradana, N. W. (2018). Determinan Agresivitas Transfer Pricing pada Perusahaan Multinasional di Indonesia (Study Empiris pada Perusahaan Multinasional yang Listing di BEI 2014-2016).

Rahadian, A. I. (2015). Analisis Faktor yang Mempengaruhi Keputusan Transfer Pricingpada Perusahaan Manufaktur di Bursa Efek Indonesia. Surabaya: Universitas Katholik Widya Mandala Surabaya. 